\title{
Quality Culture-Oriented Leadership Model Head of Islamic State Senior High School in Palu
}

\author{
Taufik \\ MTsN 4 Kota Palu, Palu 123456, Indonesia.
}

\begin{abstract}
Three schools implementing a quality culture-oriented leadership model are MAN 1, MAN 2, and MAN Insan Cendekia in Palu. This research aims to find and explain the development of culturally oriented leadership models in improving education quality in Islamic schools in Palu. This research has been conducted through interview techniques, documentation, and observations in which data results are studied and analyzed based on leadership theory. The result of this research finding is that the successful application of quality culture-oriented leadership occurs because the head of Islamic schools can develop three models of leadership in their schools: (1) transactional leadership model oriented to the ability of the head of Islamic school in meeting the needs of teachers, education staff, and students to improve the progress and quality of Islamic school education; (2) transformative leadership model that provides the understanding of the head of Islamic school on the school's need and appreciation for the efforts made by education implementers to advance the education in Islamic school; (3) Visionary leadership model that can make Islamic school can realize the achievements of their vision well in the process of organizing education. Through these three models, quality-oriented leadership was developed in MAN 1, MAN 2, and MAN Insan Cendikia in Palu.
\end{abstract}

Keywords: Leadership, Head of Islamic School, quality-oriented

\section{Introduction}

Islamic School is an important institution in carrying out the educational process. Therefore, Islamic schools should be managed by leaders who have the basics and reasonable leadership requirements to improve the quality of education and human resources. The head of the Islamic school plays a vital role in moving various components in the school so that the teaching and learning process runs well. The realization of quality Islamic schools is only possible by the headmaster as an effective education leader. Fred M. Hechinger explained that a good principal should lead an excellent Islamic school, while a nasty principal leads a bad Islamic school. It was discovered that Islamic schools failed to turn into successes. Conversely, a successful Islamic school can suddenly decline in quality because of the leader. The rise and fall of the quality of Islamic schools depend mainly on the quality of the headmaster (Daryanto, 2011).

It confirms the head of the Islamic school to understand the primary duties and functions as an educational leader. The head of an Islamic school is expected to realize quality human resources and quality educational institutions. The head of the Islamic school is a formal leader who cannot fill with people without being based on specific considerations and procedures. Therefore, the head of the Islamic school is responsible for carrying out leadership functions related to achieving educational goals and creating a quality cultured Islamic school climate.

The most significant disadvantage of educational institutions in Indonesia is that they do not have a transparent quality culture development base. Educational institutions are only developed based on economic models to produce workers' human resources that have been designed according to the prevailing economic value system. Thus, it is not surprising that the graduate of education only wants to be a job seeker and helpless human being, not a creative human being creator of welfare linkages in a cycle of various benefits. The concept of quality culture as a bureaucratic approach is a concern for all institutions. Quality culture development is a normative approach that can support real change. Not only that, developing a 
quality culture can take into account the diversity of contexts and make room for creativity and accommodate new ways to develop the quality culture itself. In a quality culture, quality is not just a discourse but must be realized to produce changes in the value system.

As part of quality improvement, quality culture becomes an accepted concept to support the development process in education (Harvey, L., \&Stensaker, B, 2008). Quality culture is a pattern of habits, beliefs, and behaviors that concern quality. Islamic schools or organizations need to have a positive quality culture (Kausar, S, 2014). Malhi R. S. (2013) stated that quality culture is a shared system of values, beliefs, and norms that focuses on pleasing customers and continuously improving products and services. An organization with a quality culture is deeply embedded in almost every aspect of its life, including hiring and promotion, employee orientation and ongoing training, compensation, management style, decision making, organizational structure, work processes, and office layout. In a quality culture, "quality" is a way of life, a principle of quality reflected in the organization's practice and behavior.

Quality orientation in education in Islamic schools is essential, must be supported and developed to respond to the tendency of global competition. The impact occurs in education with the emergence of several studies on the quality of education. Quality is the work and cultivation of humans. Therefore the fundamental thing is how the transformation of the values contained in it is carried out. Transformation of quality values is only possible in the social context of the leading education units, namely Islamic schools. In this context, educational leadership's transformation of quality values needs to be questioned (Anwar, S, 2014).

Several research studies over the past decade have established a significant function of educational leadership in developing Islamic school quality culture in general (Grace, G, 1995). There is evidence that leadership is essential in developing organizational quality (Blanton, C, 1991). For example, Gore E. W (1993) states that the most quality management approach available to organizations, leadership, vision, and culture are essential elements in Islamic school if there is a significant and permanent change. Aspin et al. (1994) argue that the functions and tasks that have been identified are related to the promotion. In the quality of education, the primary way is the responsibility of the head of the Islamic school, which is required by leadership and management exercises from the Islamic school and Islamic school system Aspin et al. (1994). Paine et al. recognize the importance of quality culture-oriented leadership in Islamic school education. Which discusses the concept of Total Quality of Education (TQE) as a model for an Islamic school, mentions that a system where a person works requires quality-oriented leadership (Paine, L. S., 1994). Leadership is also essential for developing missions and objectives, working consistently toward Islamic school improvement goals and missions (Berry, G., 1997).

Developing the quality culture of Islamic school education through leadership in Islamic schools is very appropriate because quality culture is a system that reduces educational problems and as a model that prioritizes sustainable improvement. Quality culture in leadership offers new philosophies, methods, and strategies for improving the quality of education. Hadis and Nurhayati (2012) stated that through the implementation of integrated quality management in educational institutions, it is expected that the deterioration of the quality of Indonesian education can be improved, which can ultimately improve the quality of Indonesian human resources in the present and the future. The development of quality culture in Islamic school leadership is carried out by improving services to meet the wishes and expectations of the customer. Customers in education are diverse into three groups, namely: (1) students who directly receive services, (2) parents, student sponsors who have direct interests individually and institutionally, (3) parties who have an essential role, although not directly such as the government and society as a whole. This diversity of customers makes all educational institutions focus on customers' desires and develop mechanisms to respond to them (Sallis, Edward, 2011).

As one of the educational institutions, Islamic schools must adopt quality-oriented leadership by changing the culture of educational leadership in Islamic schools towards continuous improvement (Kurniasih, W. D., \& Radiana, U., 2013). Islamic school quality culture itself is an Organisation Culture Values that become part of the organization's cultural values in the Islamic school. The quality culture is used as an embodiment of efforts to translate the vision into instrumental values that can be a guideline for all Islamic school components (Ahadiah, W, 2019). A positive quality culture is undoubtedly supported by leaders who have a positive attitude (Riyanti T, 2016).

The leadership carried out by the Head of Madrasah Aliyah Negeri (MAN) in Palu, namely MAN 1 Palu, MAN 2 Palu, MAN Insan Cendekia Palu, commits to realizing quality culture-oriented leadership. It is 
evident in the strenuous efforts they made in realizing the vision of their mission of Islamic school, related to realizing outstanding, independent, and environmentally-minded learners based on faith and piety. In their leadership to develop education, the head of Islamic schools in Palu always makes innovations oriented to improving the quality of Islamic schools. No wonder, along with the development of science and technology and in the face of the demands of society, the leadership of Islamic schools in Palu can realize excellent human resources that are clever, creative, innovative, and able to read future trends. They also have the skills to enter the Business World or the Industrial World or continue to college. In carrying out the leadership, the head of MAN in Palu made breakthroughs and concrete steps to keep the dignity of MAN. Based on these conditions, the study examined the leadership model of the Head of Islamic School, which is oriented to MAN quality culture in Palu.

\section{Materials and Methods}

Based on the focus of research on portraiture of a life that includes both individuals and groups, this study is case study research. The case study is a research method that uses a qualitative approach. Creswell (1998) proposes several characteristics of a case study: (1) identifying "cases" for a study; (2) The case constitutes a "system bound" by time and place; (3) Case study uses various sources of information, the data collected to provide a detailed and in-depth description of the response of an event and (4) Researchers will "spend time" describing the context or setting for a case.

Based on observations and combining previous factual information, social conditions, geographical, and internal situations at the research site, this study was conducted at three research sites in Palu, case studies in MAN 1 Palu, MAN 2 Palu, and MAN Insan Cendekia Palu. The target of this research is innovative measures implemented performance in improving the quality culture and the leadership of the head of Islamic school, which is oriented towards quality culture.

In this study, the techniques and data collection tools are interviews and questionnaires. Interviewing is one of the data collection techniques done by dealing directly with the interviewee, but can also be given a list of questions first to answer on other occasions (Noor J., 2011). The interview method strengthens and clarifies the data obtained by the leadership model in Palu. Besides the interview, data collection is also carried out with documentation related to essential records, both from institutions or organizations and individuals (Hamidi, 2010). This research uses the documentation method to search for leadership data of the head of the Islamic school in Palu.

Data analysis techniques are carried out with a series of activities to process into a set of research results, both in the form of innovation discoveries and hypothetical truths (Hashim M., 2019). Data analysis techniques are carried out by finding, identifying, and systematically compiling data. Data is obtained from interviews, field records, and documentation by organizing data into categories, describing into units, synthesizing, compiling into patterns, choosing which ones are important and studied, then forming conclusions (Sugiyono, 2012). Data analysis techniques are carried out with a series of activities to process data that has been collected from the field into a set of meaningful and valuable results to solve the problem as a result of research 


\section{Results and Discussion}

The Head of Islamic school has an essential role in every educational institution. In reality, Islamic schools at any level have the desire to realize an effective Islamic school so that the resulting output can answer the community's needs and the demands of the times. However, because of some of its things, not a few Islamic schools experience obstacles in realizing this desire into something tangible (E. Mulyasa, 2014). The essential problem point, in this case, is the inability of the head of the Islamic school to realize quality culture-oriented leadership in realizing the vision that has been set and based on the agreed mission.

The management of Islamic schools and the vital role of the head of Islamic school, in essence, covers a broad scope, including studentship, building, personal of Islamic school, finance, facilities, teaching and learning processes, student services as well as an Islamic school and community relations. In addition, management also includes matters of leadership, communication, and internal and external relations (Rohiat, 2008). The management is the activities of the head of the Islamic school in handling the duties and obligations in the school. Based on this, in an Islamic educational institution, applying a culturally oriented leadership model of the quality of the head of an Islamic school has a significant role in realizing the effectiveness of an institution, which in the following process the goals can be adequately achieved. Therefore, to find a point of relevance between the leadership model of the head of Islamic school oriented to a quality culture in Islamic educational institutions.

Based on the field research and literature studies, the leadership model in MAN 1, MAN 2, and MAN Insan Cendekia Palu oriented quality culture can be identified that the era of industrial revolution or change has provided great opportunities for the headmaster to develop leadership oriented to quality culture. The various challenges and threats come alternately in this era, so it is needed a cultural orientation of quality leaders in Islamic schools (Aan Komariah \& Cepi Triatna, 2010). The presence of MAN leadership model figures in Palu oriented to quality culture will build quality commitment and constantly update according to stakeholder demands. MAN quality culture-oriented leadership in Palu will improve the quality of Islamic school education. The quality culture-oriented leadership model developed by the head of MAN in Palu is carried out with the following three models.

\section{Transactional Leadership Model}

The transactional leadership model is a leadership model that emphasizes the tasks carried out by subordinates. The head of the Islamic school designs the work and mechanisms, and the staff is someone who carries out tasks according to their abilities and expertise (Komariah \& Triatna, 2005). The transactional leadership of the head of the Islamic school in Palu is more focused on the role of a manager, which has considerable engagement space in managerial procedural aspects in managing education oriented to the quality culture of the Islamic school.

In this case, a transparent work system refers to a task carried out in exchange for being received following the degree of sacrifice in work. The transactional model makes the head of an Islamic school in Palu can run a quality culture-oriented education. The well transactional processes make quality culturebased educational activities can also run well. As a leader, the head of the Islamic school can lead well, while subordinates can also carry out tasks to improve the quality of education. Transactional leadership carried out by the head of Islamic school can move educational activities oriented to improving quality culture education in an Islamic school.

It can happen because the transactional leadership model's relationship pattern is based on a reciprocal system (transaction) that is very profitable for the head of Islamic school and education implementer, both teachers and education staff. The transactional leadership model developed by the head of the Islamic school in Palu can understand the basic needs of the education implementers, can find solutions to implementers' work well. The headmaster, teachers, and education staff can fill and complement each other in their duties oriented to a quality culture in an Islamic school.

Through the transactional leadership model, the headmaster can lead the Islamic education institution, moving the world of education-oriented to quality culture. The transactional leadership makes all education implementers, namely the headmaster, teachers, and education staff work well to improve the quality of Islamic education institutions in Palu. No wonder MAN 1, MAN 2, and MAN Insan Cendekia can be quality educational institutions consistently, because the head of an Islamic school can build quality culture-oriented leadership based on transactional leadership models. 


\section{Transformational Leadership Model}

The transformational leadership model is a response to the challenges of a dynamic age. It is based on the need for self-esteem and fosters awareness in leaders to do their best following the study of management and leadership development that views human beings, performance, and organizational growth as mutually influential (Komariah \& Triatna, 2005). Transformational leaders have far-reaching insights and strive to improve and develop the organization not for now but for the future (Komariah \& Triatna, 2005). According to Covey and Peters (Komariah and Triatna, 2005), a transformational leader has a clear vision and holistic idea of how the organization when the objectives have been achieved (Mulyasa, 2013). It confirms that transformational leaders base themselves on future ideals, regardless of whether the vision is visionary in the sense everyone recognizes as a great and fundamental vision.

The head of the Islamic schools in Palu has practiced the transformational leadership model. The leadership has always oriented a culture towards needs and appreciation for the performance of teachers and education staff in building a quality culture. The head understands the fundamental education needs and can organize teachers and education staff in the school. The head of the Islamic school in Palu practices an excellent appreciation to the education implementers. The reciprocal relationship of the head of the Islamic school with the teacher and education staff goes well. It has a tangible impact on the quality of Islamic school education in Palu.

From here, the transformational leadership carried out by the head of Islamic schools in Palu can realize the vision of the respective Islamic school, which rests on quality culture. The quality culture that prioritizes improving the quality of education in Islamic schools can be implemented well by the heads of Islamic schools in Palu. The headmaster can realize the education quality culture. So that MAN 1, MAN 2, and MAN Insan Cendekia in Palu continue to be a quality school and get high public trust consistently through transformational leadership.

\section{Visionary Leadership Model}

The leader should be able to formulate the vision to be achieved through the leadership work. The vision creates a quality education system that can survive and develop to meet the demands and ideals. However, the vision can accommodate good relationships among the person in carrying out the duties and functions and in pursuing the career. Leadership that is willing with demands will realize the improvement of the quality of education-oriented to quality culture. It needs the leadership that has a vision (visionary leadership), namely, leadership that focuses on engineering a challenging future and becomes a superior agent of change and an organizational direction maker who understands priorities, a professional coach, and can guide other personnel towards the professionalism of the expected work (Mulyasa, 2013).

John Adair (Komariah and Triatna, 2005) suggests the characteristics of visionary leadership are having personal integrity; have enthusiasm for the development of the institution; develop the warmth, culture, and climate of the organization; have a calmness in organizational management; and firm and fair in taking institutional action/policy (Mulyasa, 2013). Visionary leadership is characterized by the ability to make a plan precisely, formulating the vision to achieve and develop the goals institution. Thus, the visionary leadership model shows a leader who can create, formulate, communicate, socialize, transform, and implement ideal thinking. That comes from the leader or the result of social interaction among organizational members and stakeholders as the ideal of the organization in the future that must be achieved or realized through the commitment of all personal.

The head leadership of the Islamic school in Palu has shown the performance of visionary leaders. The performance and experience of principals can advance education in their Islamic schools by being oriented to quality culture. The visionary ability was formed by the experience, who had a long career as head of an Islamic school. The head of Islamic schools always makes educational advances, namely educational progress oriented to quality culture. Every school led by the head of Islamic school in Palu is always advanced and qualified and has much public trust. 
Not only that, the perceptions and ideas of the head of Islamic schools in Palu have always been visionary, namely being able to read and predict the development of the quality of education in the institutions in the future. The head of an Islamic school in Palu has been able to give visionary ideas related to the school's management in the future to manage the variation character and think of teachers, education staff, and students. The variation of characters and ideas must be well organized so can be directed to perform well in building education in quality-oriented institutions. With this visionary experience and ideas, the head of the Islamic school in Palu can advance and develop a quality culture in the institution.

The visionary leadership of the head of Islamic schools in Palu makes them create innovation following the vision, commit and strive to realize the quality and the Islamic school vision and mission. The head of Islamic school focuses programs and activities on environmental structuring (adiwiyata), healthy school programs, and academic quality improvement programs. Based on visionary ability, the head of an Islamic school can realize an advanced and qualified institution by empowering teachers, education staff, and students. The head of MAN 1, MAN 2, and MAN Insan Cendekia Palu have implemented visionary leadership and created a culture of quality education.

\section{Conclusions}

Islamic school is an educational institution, the advance of institution determined by the leadership model of the head of the Islamic school. One of the leadership models that will make Islamic schools advanced is a quality culture-oriented leadership model. The leadership of the head of Islamic schools focuses on efforts to manage education so that the quality of education can improve well. Three schools implementing a quality culture-oriented leadership model are MAN 1, MAN 2, and MAN Insan Cendekia in Palu. Successful leadership occurs because the head of the Islamic school can develop three leadership models, namely the transactional leadership model oriented to the ability of the headmaster to meet the needs of teachers, education staff, and students. With the fulfillment of this need, the transaction process is formed in joint performance to improve the progress and quality of Islamic school education. Second, a transformative leadership model provides the understanding of the head of an Islamic school over the school's needs and appreciation for the efforts made by education implementers. This transformative model can make the head of the Islamic school more maximal in advancing education in school. Third, the visionary leadership model can make Islamic schools realize the achievements of the vision well in organizing education. Successful of this vision achievement, so the head of Islamic school has an essential role in improving the Islamic school education quality.

\section{Acknowledgments}

Thank you to all parties involved in the research and creation process of this article, so that the writing of this article can be completed. Do not forget to say a big thank you to the principal and teachers of MAN 1, MAN 2, and MAN Insan Cendekia in Palu who have supported this research.

\section{References}

1. Ahadiah, W. Pengembangan Mutu di madrasah Dasar dalam Meningkatkan Prestasi Peserta Didik. 2017 Diakses 15 Oktober 2019 (http//digilib uinsby.ac.id/21784/5/Bab\%202pdf).

2. Anwar, S. Pengembangan Budaya Mutu dalam Meningkatkan Kualitas Madrasah di Madrasah Ibtidaiyah Negeri Kota Bandar Lampung. Jurnal Studi Keislaman, 14(2), (2014), h.455-490

3. Aspin, D.N., Chapman, J.D and Wilkinson, V.R Quality Schooling: A Pragmatic Approach to some Current Problems, Topics, and Issues, Cassel, London. (1994), h. 20

4. Berry, G. Leadership and the development of quality culture in schools. International Journal of educational management, 11 (2), (1997), h. 52-64

5. Blanton, C. A Principal's vision of excellence: achieving quality through empowerment praxis, Vol. 3 No. 2, (1991), h. 1-2, 9

6. Creswell, John W. Qualitative Inquiry and Research Design: Choosing Among Five Traditions. London: $\quad$ SAGE Publications, 1998.

7. Daryanto, Kepala madrasah Sebagai Pemimpin Pembelajaran, Yogyakarta: Gava Media, 2011, Cet. I. 
8. Gore, E, W. Jr. “Total quality management in education”. In Hubbard, D.L. (Ed), Continuous Quality Improvement: Making the Transition to Education, (1993) Prescott Publishing Company, Maryville, MO, h. 357-358.

9. Grace, G. School Leadership: Beyond Educational Managemen. (1995) The Falmer Press. London Hadis dan Nurhayati. 2012. Manajemen Mutu Pendidikan. Bandung: Alfabetha.

10. Hamidi. 2010. Metode Penelitian Kualitatif. Malang: UMM Press.

11. Harvey, L. and Stensaker, B. Quality culture: Understandings, boundaries, and linkages. European Journal of Education. 2008.

12. Hasyim, Adelina. 2019. Metode Penelitian dan Pengembangan di Sekolah. Yogyakarta: Graha Ilmu. Kausar, S. Impact of Quality Culture on Employees' Motivation: A Study on Education Sector of Pakistan, 22 (7), 2014.

13. Komariah \& Triatna. 2005. Visionary Leadership Menuju Sekolah Efektif. Jakarta: Bumi Aksara.

14. Komariah, Aan. dan Cepi Triatna, Visionary Leadership Menuju madrasah Efektif, Jakarta: PT. Bumi Aksara, 2010

15. Kurniasih, W. D. dan Radiana, U. Pengembangan Budaya Mutu di madrasah Dasar Swasta Bruder Melati Kota Pontianak. 2013.

16. Malhi, Ranjit Singh. "Creating and Sustaining: A Quality Culture," Journal of Defense Management, 2013.

17. Mulyasa, E. Manajemen Kepemimpinan Kepala madrasah, Jakarta: PT. Bumi Aksara, 2014

18. Mulyasa, E. Menjadi Kepala madrasah Profesional, Bandung: PT. Remaja Rosdakarya, 2013

19. Noor, J. Metodologi Penelitian. Jakarta Kencana Prenada Media Group, 2011.

20. Paine, L. S. "Managing for Organizational Integrity." Harvard Business Review, March-April, 72 (2), (1994). Hal. 106-117

21. Riyanta, T. Mengembangkan Budaya Mutu madrasah Melalui Kepemimpinan Transformasional. Jurnal Manajemen Pendidikan. UNY. 2016.

22. Rohiat, Kecerdasan Emosional Kepemimpinan Kepala madrasah, Bandung PT. Refika Aditama, 2008

23. Sallis, Edward. Total Quality Managemen in Education. Jogjakarta: Ircisod, 2011.

24. Sugiyono. 2012. Metode Penelitian Kualitatif. Bandung: Alvabeta. 